D. Ercan Oruc, ${ }^{1}$ S. Pokharel, ${ }^{2 *}$

A. J. Hirneisen, ${ }^{3}$ and C. N. Cutter ${ }^{4}$

${ }^{1}$ Dept. of Chemistry and Fermentation Sciences, Appalachian State University, Boone, NC 28608, USA

${ }^{2}$ Animal Science Dept., California Polytechnic State

University, San Luis Obispo, CA 93407, USA

${ }^{3}$ Penn State Extension, 1238 County Welfare Road, Suite

110, Berks County Ag Center, Leesport, PA 19533, USA

${ }^{4}$ Dept. of Food Science, Pennsylvania State University,

University Park, PA 16802, USA
PEER-REVIEWED ARTICLE

Food Protection Trends, Vol. 41, No. 5, p. 485-500 Copyright $^{\bullet}$ 2021, International Association for Food Protection 2900 100th Street, Suite 309, Des Moines, IA 50322-3855, USA

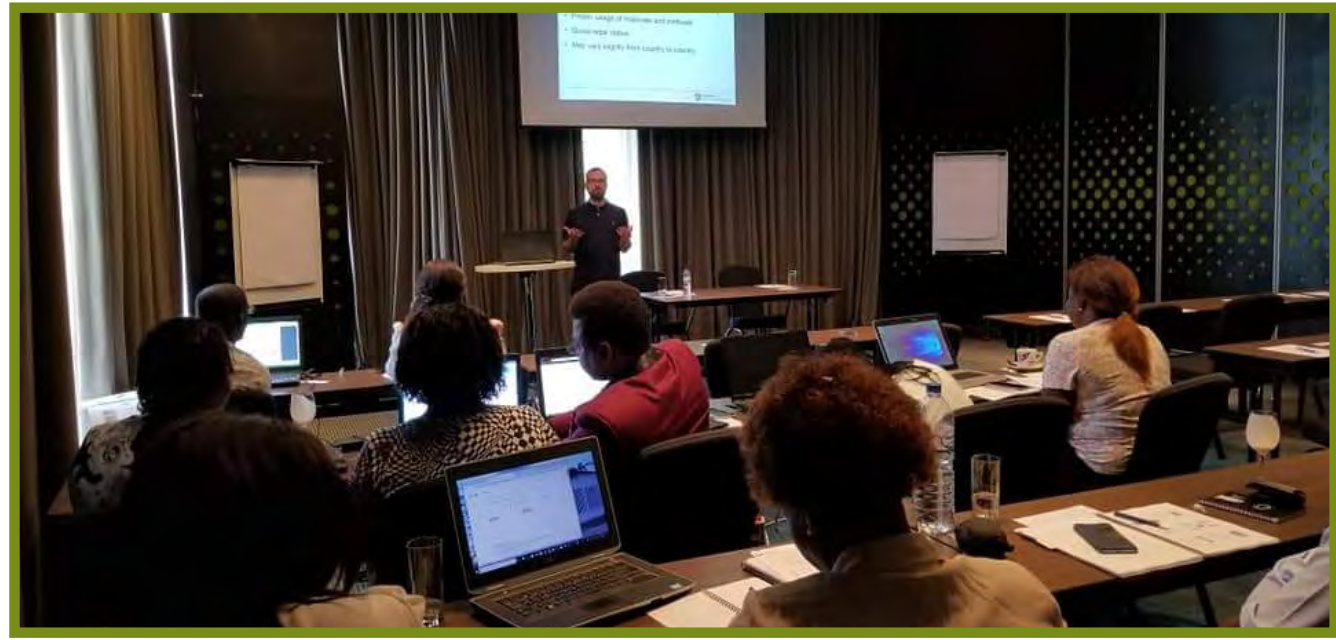

\title{
A Food Safety Laboratory Curriculum Significantly Improves Knowledge, Behaviors, Attitudes, and Handwashing Skills of Laboratory Personnel in East and South Africa
}

\section{ABSTRAGT}

In 2017, a needs assessment conducted in Africa reported that personnel in food safety testing laboratories have deficiencies in lab safety, quality assurance, validation of test methods, metrics, sampling protocols, management, accreditation, methodologies, data analyses, and interpretation. The purpose of this study was to develop and deliver a curriculum on the basis of the identified needs for laboratory personnel in East Africa (Ethiopia, Uganda) and South Africa (Mozambique) and gauge the impact of the training on several attributes. Prior to and immediately after the workshop, laboratory personnel were evaluated for knowledge, behavior, attitudes, and handwashing skills. A significant increase was found in participants 'knowledge, on the basis of the results of the pre- and posttests on the topics delivered by the curriculum $(P \leq 0.05)$. Additionally, behaviors of laboratory personnel positively changed concerning good laboratory practices and quality management systems and participants' attitudes toward general laboratory practices, regulations, and understanding of continuous training improved significantly. Moreover, handwashing skills were significantly improved after the workshop. This curriculum and results may be used to develop continuous education programs for personnel of food testing laboratories to enhance the safety of a global food supply.

\section{INTRODUCTION}

Food safety is a relevant discipline that connects people around the world. Food produced and packaged in one geographical area may significantly impact people living on the opposite side of the world. The global agricultural trade has a value worth more than US\$1.1 trillion, and food trade is important to fulfill every country's food demand (2). This observation makes the global food system highly connected and intertwined (2). The trade value of a global food system will increase in years to come to feed an ever-growing population. Globalization also carries a significant benefit to countries with developing economies that can pick cheaper, but safe, food products. However, the safety of food that is being produced, packaged, shipped, and consumed by the end user is of primary concern. 
In 2015, foodborne hazards were responsible for 137,000 deaths and 91 million acute illnesses affecting African children under the age of 5 (20). The burden of foodborne illness is most severe in low- and middle-income African countries. Consumption of unsafe food leads to gastroenteritis and other food poisoning symptoms, mostly affecting infants, young children, pregnant women, and the elderly with a diminished immune system (20). Therefore, a safe and nutritious food supply is key to a healthy lifestyle. However, many Africans lack safe and nutritious food ( 1 , $6,7,19)$. Given these limitations, African countries are slowly adopting global food safety systems and modernizing international trade. Yet, many countries still lack the resources, including those from the government sectors, to ensure safe consumption of food products $(1,6)$. In such instances, the Global Food Safety Initiative capacity-building programs in the African region become beneficial $(1,7)$. For the international food trade, food safety standards and modern practices are reviewed and verified by the importer to be in compliance. Given these approaches, training, education, and assessment of laboratory practices are an essential foundation for a global food safety system (1).

Recently, a study assessed practices and procedures in African food safety testing laboratories in three African nations, Ethiopia, Uganda, and Mozambique. Several issues, such as lab safety, quality assurance, validation of test methods, sampling protocols, data management, data analysis, training, and accreditation were addressed (14, 18). Several gaps and issues were identified in laboratory infrastructure, sample handling, testing methodologies, data analysis, and professional development (14). General findings on food standard systems, inspection mechanisms, and laboratory capabilities of several African Nations can be found at an annex provided by Food and Agriculture Organization of the United Nations (5). On the basis of the results, it was determined that identified food safety gaps and issues could be addressed through face-to-face training in testing laboratories. Hence, this study aims to develop, deliver, and evaluate a needs-based curriculum that can be used to train food safety laboratory personnel in East and South Africa.

\section{MATERIALS AND METHODS}

\section{Human subjects research protocols}

The institutional review board at Pennsylvania State University (IRB STUDY00008250) approved the recruitment process, project design, consent forms, lectures, laboratories, activities, pre- and postexams, surveys, and handwashing protocols.

\section{Recruitment process}

In 2017, phase I of this study involved an on-site comprehensive needs assessment of food safety laboratories in East and South Africa: Ethiopia, Uganda, and Mozambique (14).
After approval by Pennsylvania State University Institutional Review Board, potential employees or personnel from food safety testing laboratories, identified in phase I of the study (in-person visit) and located in East and South Africa, were contacted via e-mail. The interested personnel in those laboratories who were fluent in English, were 18 years or older, and who expressed an interest in participating in this training were recruited for this research project. As a result of this recruitment process, 19 participants from Ethiopia, 11 participants from Uganda, and 11 participants from Mozambique completed the training program.

\section{Consent}

Personnel from participating food safety testing laboratories in East and South Africa received a consent form to be part of the research via e-mail prior to the training (December 2018) and a paper version of the consent form in person and on-site from the principal investigator (C. N. Cutter) in January or February 2019. All participants were fluent in writing, reading, and speaking English and did not require additional translation to participate in the program; additional clarification was provided to participants that this research would have no impact on employment status. The consent form disclosed the procedures to be performed, participation was voluntary, and there were adequate provisions to maintain the privacy interests of subjects.

Completed consent forms, paper-based surveys, and a memory card with handwashing videos resulting from the research will be stored for 3 years, following the completion of the study, and will be destroyed and/or removed from the card at that time.

\section{Development and delivery of the Food Safety Laboratory Workshop}

During the needs assessment portion of the study (14), laboratory personnel expressed interest in improving laboratory practices via additional training. On the basis of the needs assessment, we developed a comprehensive curriculum (Table 1) to address a number of topics, including, but not limited to, lab safety, quality assurance, validation of test methods, sampling protocols, management, lab safety (including handwashing), accreditation, methodologies, data analyses and interpretation, maintenance, and troubleshooting. Table 1 outlines the schedule of the 5-day Food Safety Laboratory Workshop. The curriculum was administered in English in each country (Ethiopia, Mozambique, and Uganda) in Africa in January and/or February 2019. The workshop included face-to-face instruction and breakout sessions for laboratory personnel. The first 2 days of the curriculum were designed to deliver fundamentals of microbiology, aseptic sampling techniques, and pathogen detection methods. On the third day, the importance of International Organization for Standardization and the International Electrotechnical Commission (ISO/IEC) 17025 and quality 
management steps in a food safety laboratory were discussed. Then, the key steps to generate technically valid results were discussed. These key steps included statistical methods to create sampling plans, guidelines for the validation of microbial detection methods, as well as guidelines for the calibration and validation of laboratory equipment $(4,17,18)$. On the fourth day, statistical process control tools that can be used in a food safety laboratory were explained to achieve process stability and variance reduction (11). Moreover, the importance of record keeping and education was emphasized to maintain or improve good laboratory practices (GLP). On the fifth day, food laws and regulations, such as Codex Alimentarius, hazard analysis and critical control point, ISO standards, British Retail Consortium, International Featured Standard were addressed.

To facilitate the lectures, different breakout sessions were designed. For example, in one of the breakout sessions, the participants were asked to prepare standard operating procedures (SOP) for a selected food item to include (i) transport (how the sample was packaged and sent to the lab for analyses); (ii) preparation or processing of the sample (time frame for sampling, homogenization of food sample [stomaching, blending, rinsing, and swabbing], sample size and measurement [volume versus weight], and choice of buffer); (iii) dilution scheme and reagents; (iv) choice of media and/or technique (standard plate counts, molecular, immunological) for determining which microorganisms are present in the sample; (v) atmosphere and temperature for incubation of media; and (vi) presence or absence and/or enumeration or quantitation of organisms (manual versus automatic). Participants were also asked to design a continuous training plan for the laboratory by answering the following questions: Which training tools can be used? Who will be included in the training program? What kind of competency assessment can be used? How often will the training program be implemented? The details of the curriculum and breakout session activities can be found in Table 1 .

\section{Participants' demographics, evaluation of knowledge, behavior, attitude, and handwashing skills}

Participants completed a demographic questionnaire after signing the consent form and agreeing to participate in the Food Safety Laboratory Workshop. This questionnaire included 14 questions to assess the participants' age, sex, marital status, educational background, proficiency in testing methods and laboratory instruments, and their English proficiencies. Prior to and immediately after the curriculum was delivered, the participants were evaluated for knowledge, behavior, attitudes, and handwashing skills, as a means of gauging the impact of the training on the participants. To evaluate the change in the participants' knowledge, we conducted pre- and posttests. The pre- and posttests included the same 30 true or false and multiple choice questions. Moreover, participants completed the same behavior and attitude surveys before and after the delivery of the curriculum. The behavior survey had 24, 6-point Likert scale questions, and the attitude survey included 18, 6-point Likert scale questions. Moreover, participants' handwashing techniques were monitored to assess their representative skills before and after the completion of the workshop. The handwashing activity videos were recorded by using a Canon Powershot (Tokyo, Japan) and saved to an external memory card (Samsung Flash, Seoul, South Korea). Then, the handwashing techniques were scored, on the basis of the timing, movements, and sounds produced during the handwashing procedure. The scoring system (Table 2) was developed by using the method of the Consensus Measurement in Hand Hygiene project, with some modifications $(12,16)$.

\section{Data analysis}

The total number of responses to each question in the demographic questionnaire, behavior, and attitude surveys was counted and reported as percentages. The pre- and posttests were evaluated on a 100 -point scale. Moreover, the handwashing skill data were calculated over 12 maximum points. Microsoft Office Excel 2013 (Microsoft Corp., Redmond, WA) was used to calculate data points and basic descriptive statistics (e.g., mean, standard deviation, standard error of the mean, percentage of responses, and observations). Statistically significant differences in pre- and posttest results and handwashing skill scores were calculated by using paired $t$ test ( $\alpha=0.05$; Minitab, State College, PA).

\section{RESULTS AND DISCUSSION}

The topics and agenda for the Food Safety Laboratory Workshop were developed and based on the needs assessment conducted by Pokharel et al. (14). The workshop was delivered in Uganda, Mozambique, and Ethiopia in January and February 2019. The Food Safety Laboratory Workshop agenda is provided in Table 1. The aim of the workshop was to improve the knowledge, behavior, attitude, and handwashing skills of participants who work in food testing laboratories.

\section{Demographic characteristics of participants}

Table 3 demonstrates the demographic characteristics of participants from the food safety testing laboratories in East and South Africa. In Uganda, $60 \%$ of participants were between 30 to 39 years old. In Mozambique and Ethiopia, the ages of participants ranged from 21 to 59 years. In all three countries, most of the participants had bachelor's (4-year college) degrees. In Uganda, most of the participants had biology or agriculture backgrounds. In Mozambique and Ethiopia, the participants' educational backgrounds were more diverse. Similarly, most of the participants in the needs assessment study conducted by Pokharel et al. (14) also had biological and agricultural backgrounds, with an average age of 39 years. In Uganda and Mozambique, most participants (80\%) indicated they were "proficient" with lab instruments. However, $37 \%$ of 


\section{TABLE 1. Food Safety Laboratory Workshop topics, delivery methods, and agenda}

\begin{tabular}{|c|c|c|}
\hline & & Agenda \\
\hline Day 1 & & Food microbiology: part 1 (type of delivery: face-to-face lectures) \\
\hline 10:00 a.m. & Introductions & Instructors and class participants \\
\hline 10:30 a.m. & Data collection & Demographic data collection and pretest assessments \\
\hline 11:00 a.m. & & Introduction to food microbiology \\
\hline 1:00 p.m. & & Spoilage and indicator microorganisms \\
\hline $1: 45$ p.m. & & Escherichia coli and other Shiga toxin-producing E. coli \\
\hline $2: 45$ p.m. & & Staphylococcus aureus and Listeria monocytogenes \\
\hline 3:45 p.m. & & Salmonella and Campylobacter \\
\hline 4:30 p.m. & Activity & Glo Germ and handwashing exercise \\
\hline Day 2 & $\begin{array}{l}\text { Food microbiology: part } 2 \text { (type of delivery: } \\
\text { face-to-face lectures and breakout sessions) }\end{array}$ & \\
\hline 9:00 a.m. & & Molds and mycotoxins \\
\hline 9:45 a.m. & & Parasites, viruses, and additional bacterial pathogens \\
\hline 11:00 a.m. & & Methods for sampling food products \\
\hline 1:00 p.m. & & Methods for bacterial dilution and enumeration \\
\hline 2:00 p.m. & & Immunological-based methods for pathogen detection \\
\hline 3:30 p.m. & & DNA-based methods for pathogen detection \\
\hline 4:00 p.m. & Activity & Breakout session I: sample preparation \\
\hline Day 3 & & $\begin{array}{l}\text { Quality assurance, validation of laboratory test methods, data } \\
\text { analyses, data interpretation (type of delivery: face-to-face } \\
\text { lectures and breakout sessions) }\end{array}$ \\
\hline 9:00 a.m. & & Basic laboratory practices \\
\hline 10:00 a.m. & & ISO/IEC 17025 and control points in microbiology lab \\
\hline 11:00 a.m. & & Sampling plans: data analysis \\
\hline $1: 00$ p.m. & & Data analysis: formulas \\
\hline 2:00 p.m. & Activity & Breakout session II \\
\hline & & Dilution and plating calculation example \\
\hline 3:00 p.m. & & $\begin{array}{l}\text { Validation of microbiological methods and calibration of } \\
\text { equipment }\end{array}$ \\
\hline 4:00 p.m. & & Guidance on laboratory equipment calibration \\
\hline Day 4 & & $\begin{array}{l}\text { Statistical process control for laboratory personnel, record } \\
\text { keeping, troubleshooting (type of delivery: face-to-face lectures } \\
\text { and breakout sessions) }\end{array}$ \\
\hline 9:00 a.m. & Activity & Introduction to ATP bioluminescence \\
\hline & & Hands-on exercise: ATP bioluminescence \\
\hline 10:00 a.m. & & Microbiological troubleshooting \\
\hline 10:45 a.m. & & Introduction to statistical process control \\
\hline $1: 00$ p.m. & & Statistical process control tools \\
\hline 2:00 p.m. & & Record keeping \\
\hline 3:00 p.m. & Activity & Breakout session III \\
\hline & & Group exercise: developing continuous training programs \\
\hline 4:00 p.m. & & Group presentation: developing continuous training programs \\
\hline
\end{tabular}




\section{TABLE 1. Food Safety Laboratory Workshop topics, delivery methods, and agenda (cont.)}

\begin{tabular}{l|l|l}
\multicolumn{2}{l|}{} & \multicolumn{1}{c}{ Agenda } \\
\hline Day 5 & & $\begin{array}{l}\text { Accreditation, wrap-up, FAQs, evaluation of program (type of } \\
\text { delivery: face-to-face lectures and breakout sessions) }\end{array}$ \\
\hline $9: 00$ a.m. & & Accreditation: the environment of food safety standards \\
\hline $10: 00$ a.m. & & Codex Alimentarius standards \\
\hline $11: 00$ a.m. & & Question and answer session with instructors \\
\hline $11: 15$ a.m. & Data collection & Posttest and assessments \\
\hline $12: 00$ p.m. & Evaluations and awarding of certificates & \\
\hline
\end{tabular}

\section{TABLE 2. Rubric to assess hand-washing skills of participants}

\begin{tabular}{l|l} 
Steps & Action (points awarded) \\
\hline 1. Wet hands & No $(0)$; partial $(1)$; all (2) \\
\hline 2. Soap application & No $(0)$; yes $(2)$ \\
\hline 3. (i) Lather & (i) No vigor $(0)$; minimal vigor $(1)$; vigorous $(2)$ \\
\hline (ii) Lather time & (ii) 5 s or less $(0) ; 6$ to 10 s $(1)$; more than 10 s $(2)$ \\
\hline 4. Rinse & No $(0)$; partial $(1)$; all $(2)$ \\
\hline 5. Dry & No $(0)$; partial (1); all (2) \\
\hline
\end{tabular}

the participants in Ethiopia stated their proficiency level with the instruments as "somewhat proficient," and $16 \%$ of them were not sure about proficiency level. The number of participants conducting microbiological testing was higher in Uganda (80\%) and Ethiopia (63\%), with only $20 \%$ in Mozambique, due, in part, to the high volume of chemical testing that is performed in foods (50\% participants). Participants in all three countries were exposed to English as a second language in elementary and middle schools. As a result, participants describe English language proficiency as good to very good for reading, speaking, writing, and listening. Moreover, the participants' household members also speak English as a second language in Uganda. However, only $30 \%$ of the participants' household members speak English as a second language in Mozambique, where the major spoken language is Portuguese. Similarly, the percentage of household members speaking English as a second language is higher in Ethiopia (63\%) when compared with Mozambique. This last demographic aspect is important, given that the training materials and lectures were presented in English.

\section{Evaluation of knowledge and skills before and after the training program}

On the basis of the results of the needs assessment (14), we developed the course curriculum to address the following topics: general food microbiology; microbial detection methods; lab safety (including handwashing); quality assurance; validation of test methods and equipment; metrics; sampling protocols; data management; accreditation process; development of continuous training programs; understanding the need for record keeping and international laboratory and food safety standards (Table 1).

To assess the changes in participants' skills as a result of the workshop, hand-washing activities were monitored and evaluated by using the scoring rubric provided in Table 2. Hand-washing skill was observed before the start of the food safety laboratory workshop and immediately after the workshop delivery. When pre- and postscores of hand-washing skills were compared (Table 4), Ugandan participants had increased their scores (46\%) significantly, followed by participants from Mozambique (40\%) and Ethiopia (34\%). Overall, the handwashing score increased significantly $(P \leq 0.05)$ by $40 \%$ for all participants, from $8.1 \pm 0.40$ to $11.4 \pm 0.35$ after the training program. Hand-washing skills are important to prevent crosscontamination. Johnston et al. (9) found that poor handwashing can result in failure to remove transient pathogens on laboratory personnel's hands. Therefore, understanding the standard soap and water hand-washing technique is important in preventing pathogen transmission in the laboratory. 


\section{TABLE 3. Demographic characteristics of participants from the food safety testing}

laboratories in East and South Africa

\begin{tabular}{|c|c|c|c|c|c|c|}
\hline & \multicolumn{2}{|c|}{ Uganda } & \multicolumn{2}{|c|}{ Mozambique } & \multicolumn{2}{|c|}{ Ethiopia } \\
\hline & Responses & Total (\%) & Responses & Total (\%) & Responses & Total (\%) \\
\hline \multicolumn{7}{|l|}{ 1. Age } \\
\hline [ ] 17 or younger & 0 & 0 & 0 & 0 & 0 & 0 \\
\hline [ ] 18-20 & 0 & 0 & 0 & 0 & 0 & 0 \\
\hline [ ] 21-29 & 3 & 30 & 1 & 10 & 7 & 37 \\
\hline [ ] 30-39 & 6 & 60 & 3 & 30 & 5 & 26 \\
\hline [ ] 40-49 & 0 & 0 & 4 & 40 & 5 & 26 \\
\hline [ ] 50-59 & 1 & 10 & 2 & 20 & 2 & 11 \\
\hline [ ] 60 or older & 0 & 0 & 0 & 0 & 0 & 0 \\
\hline
\end{tabular}

\section{The highest level of education}

\begin{tabular}{|c|c|c|c|c|c|c|}
\hline [ ] Middle school & 0 & 0 & 1 & 10 & 0 & 0 \\
\hline $\begin{array}{l}\text { [ ] High school degree or equivalent } \\
\text { (General Educational Development) }\end{array}$ & 0 & 0 & 1 & 10 & 0 & 0 \\
\hline [ ] Some college level education, but no degree & 1 & 10 & 1 & 10 & 2 & 11 \\
\hline [ ] A.A. or A.S. degree (associate: 2-yr college degree) & 0 & 0 & 0 & 0 & 3 & 16 \\
\hline [ ] B.A. or B.S. degree (bachelor’s 4-yr college degree) & 6 & 60 & 6 & 60 & 6 & 32 \\
\hline [ ] M.S., M.A., or M.B.A. (master's: graduate degree) & 3 & 30 & 1 & 10 & 5 & 26 \\
\hline [ ] Ph.D. (doctoral degree) & 0 & 0 & 0 & 0 & 3 & 16 \\
\hline
\end{tabular}

\section{The year of school for continuing education cases}

\begin{tabular}{l|l|l|l|l|l|l}
\hline$[$ ] Freshman, first year & 0 & 0 & 0 & 0 & 1 & 5 \\
\hline$[$ ] Sophomore, second year & 0 & 0 & 0 & 0 & 0 & 0 \\
\hline$[$ ] Junior, third year & 0 & 0 & 0 & 0 & 0 & 0 \\
\hline$[$ ] Senior, fourth year & 0 & 0 & 0 & 0 & 3 & 16 \\
\hline
\end{tabular}

4. Expectation to enroll in an advanced degree after graduation

\begin{tabular}{|c|c|c|c|c|c|c|}
\hline$[$ ] No & 0 & 0 & 0 & 0 & 3 & 16 \\
\hline [ ] Yes & 2 & 20 & 2 & 20 & 5 & 26 \\
\hline \multicolumn{7}{|l|}{ 5. Educational background } \\
\hline $\begin{array}{l}\text { [ ] Agriculture (animal science, food science, } \\
\text { food microbiology, or food safety) }\end{array}$ & 7 & 70 & 2 & 20 & 6 & 32 \\
\hline $\begin{array}{l}\text { [ ] Biological/life sciences (biology, } \\
\text { biochemistry, botany, or zoology) }\end{array}$ & 6 & 60 & 2 & 20 & 7 & 37 \\
\hline [ ] Agribusiness & 2 & 20 & 0 & 0 & 0 & 0 \\
\hline $\begin{array}{l}\text { [ ] Business (accounting, business } \\
\text { administration, marketing, or management) }\end{array}$ & 0 & 0 & 1 & 10 & 3 & 16 \\
\hline [ ] Communication (speech, journalism) & 1 & 10 & 0 & 0 & 0 & 0 \\
\hline [ ] Education & 0 & 0 & 0 & 0 & 0 & 0 \\
\hline [ ] Engineering & 0 & 0 & 1 & 10 & 1 & 5 \\
\hline $\begin{array}{l}\text { [ ] Health related fields (nursing, physical therapy, } \\
\text { health technology, radiology, or pathology) }\end{array}$ & 0 & 0 & 1 & 10 & 3 & 16 \\
\hline [ ] Others & 0 & 0 & 3 & 30 & 3 & 16 \\
\hline
\end{tabular}




\section{TABLE 3. Demographic characteristics of participants from the food safety testing}

laboratories in East and South Africa (cont.)

\begin{tabular}{l|c|c|c|c|c|c|c} 
& \multicolumn{2}{|c|}{ Uganda } & \multicolumn{2}{c}{ Mozambique } & Ethiopia \\
\hline & Responses & Total (\%) & Responses & Total (\%) & Responses & Total (\%) \\
\hline $\begin{array}{l}\text { 6. Proficiency with lab instruments } \\
{[] \text { I do not know }}\end{array}$ & 0 & 0 & 0 & 0 & 3 & 16 \\
\hline[] Somewhat proficient & 1 & 10 & 1 & 10 & 7 & 37 \\
\hline[] Proficient & 8 & 80 & 8 & 80 & 6 & 32 \\
\hline[] Very proficient & 1 & 10 & 1 & 10 & 3 & 16 \\
\hline
\end{tabular}

7. The testing methods that currently performing in the lab

\begin{tabular}{|c|c|c|c|c|c|c|}
\hline [ ] Microbiological & 8 & 80 & 2 & 20 & 12 & 63 \\
\hline [ ] Fungal & 3 & 30 & 0 & 0 & 2 & 11 \\
\hline [ ] Toxicological (including insecticides and pesticides) & 0 & 0 & 1 & 10 & 1 & 5 \\
\hline [ ] Chemical & 2 & 20 & 5 & 50 & 5 & 26 \\
\hline [ ] Other & 3 & 30 & 1 & 10 & 4 & 21 \\
\hline
\end{tabular}

8. Previous participation in a food safety training course

\begin{tabular}{|l|l|l|l|l|l|l|l}
\hline[] Yes & 6 & 60 & 5 & 50 & 10 & 53 \\
\hline[] No & 4 & 40 & 5 & 50 & 9 & 47 \\
\hline
\end{tabular}

\section{Access to Internet}

\begin{tabular}{l|c|c|c|c|c|c}
\hline[] Phone & 10 & 100 & 9 & 90 & 19 & 100 \\
\hline[] Home & 2 & 20 & 9 & 90 & 9 & 47 \\
\hline[] Work & 10 & 100 & 10 & 100 & 19 & 100 \\
\hline
\end{tabular}

10. English language proficiency

\section{Reading}

\begin{tabular}{|c|c|c|c|c|c|c|}
\hline Very poor & 0 & 0 & 0 & 0 & 0 & 0 \\
\hline Poor & 0 & 0 & 2 & 20 & 0 & 0 \\
\hline Fair & 0 & 0 & 2 & 20 & 0 & 0 \\
\hline Good & 1 & 10 & 6 & 60 & 3 & 16 \\
\hline Very good & 9 & 90 & 0 & 0 & 16 & 84 \\
\hline \multicolumn{7}{|l|}{ Speaking } \\
\hline Very poor & 0 & 0 & 1 & 10 & 0 & 0 \\
\hline Poor & 0 & 0 & 3 & 30 & 0 & 0 \\
\hline Fair & 0 & 0 & 5 & 50 & 4 & 21 \\
\hline Good & 4 & 40 & 1 & 10 & 6 & 32 \\
\hline Very good & 6 & 60 & 0 & 0 & 9 & 47 \\
\hline \multicolumn{7}{|l|}{ Writing } \\
\hline Very poor & 0 & 0 & 1 & 10 & 0 & 0 \\
\hline Poor & 0 & 0 & 1 & 10 & 0 & 0 \\
\hline Fair & 0 & 0 & 6 & 60 & 0 & 0 \\
\hline Good & 1 & 10 & 2 & 20 & 4 & 21 \\
\hline Very good & 9 & 90 & 0 & 0 & 15 & 79 \\
\hline
\end{tabular}




\section{TABLE 3. Demographic characteristics of participants from the food safety testing}

laboratories in East and South Africa (cont.)

\begin{tabular}{|c|c|c|c|c|c|c|}
\hline & \multicolumn{2}{|c|}{ Uganda } & \multicolumn{2}{|c|}{ Mozambique } & \multicolumn{2}{|c|}{ Ethiopia } \\
\hline & Responses & Total (\%) & Responses & Total (\%) & Responses & Total (\%) \\
\hline \multicolumn{7}{|l|}{ Listening } \\
\hline Very poor & 0 & 0 & 0 & 0 & 0 & 0 \\
\hline Poor & 0 & 0 & 1 & 10 & 0 & 0 \\
\hline Fair & 0 & 0 & 8 & 80 & 2 & 11 \\
\hline Good & 3 & 30 & 1 & 10 & 7 & 37 \\
\hline Very good & 7 & 70 & 0 & 0 & 10 & 53 \\
\hline
\end{tabular}

11. Household members speaking English as a secondary language

\begin{tabular}{c|c|c|c|c|c|c}
\hline[] Yes & 10 & 100 & 3 & 30 & 12 & 63 \\
\hline[] No & 0 & 0 & 7 & 70 & 7 & 37 \\
\hline
\end{tabular}

12. Started learning to speak English language in

\begin{tabular}{l|c|c|c|c|c|c}
\hline$[$ ] Elementary or middle school & 10 & 100 & 4 & 40 & 10 & 53 \\
\hline$[$ ] High school & 0 & 0 & 2 & 20 & 6 & 32 \\
\hline$[$ ] College & 0 & 0 & 1 & 10 & 3 & 16 \\
\hline
\end{tabular}

13. Took English as a secondary language classes in the past

\begin{tabular}{l|l|l|l|l|l|l}
\hline[] No & 5 & 50 & 9 & 90 & 5 & 26 \\
\hline[] Yes & 5 & 50 & 1 & 10 & 14 & 74 \\
\hline
\end{tabular}

\section{TABLE 4. Hand-washing skills of participants before (pretest) and immediately after [posttest] the delivery of the Food Safety Laboratory Workshop}

\begin{tabular}{l|c|c|c|c|c|c} 
& \multicolumn{4}{c}{ Hand-washing skill scores (maximum 12) } \\
\hline \multirow{2}{*}{ Location of activity } & \multicolumn{2}{|c|}{ Ethiopia } & \multicolumn{2}{c}{ Uganda } & \multicolumn{3}{c}{ Mozambique } \\
\hline Time of activity & Pretest & Posttest & Pretest & Posttest & Pretest & Posttest \\
\hline Average score & $8.60 \mathrm{~B}^{a}$ & $11.50 \mathrm{~A}$ & $8.00 \mathrm{~B}$ & $11.67 \mathrm{~A}$ & $7.83 \mathrm{~B}$ & $11.00 \mathrm{~A}$ \\
\hline Standard deviation & 2.55 & 0.84 & 2.00 & 0.50 & 1.72 & 1.10 \\
\hline
\end{tabular}

${ }^{a}$ Different letters $(A$ and $B)$ within a row shows statistically significant data $(P \leq 0.05)$.

To assess the changes in participants' knowledge, pre- and posttests were given. This test included 30 questions on the topics covered during the workshop, such as fundamentals of food microbiology, GLP, regulations and standards, statistical methods to prepare sample plans, interpretation of the results, and process control. The average test results are provided in (Table 5). As a result of this educational program, the participants' knowledge increased significantly in all countries $(P \leq 0.05)$. Overall, the average knowledge on several of the topics covered during the workshop increased by $28 \%$. Recent studies have demonstrated a similar effect when training has improved the food handlers' food safety knowledge $(3,8)$. The increase in knowledge significantly affected the posttest given afterwards. This observation is important because continuous training is needed to keep laboratory personnel's knowledge up to date, especially when new analytical techniques are evolving rapidly (15).

\section{Participants' behaviors and attitudes}

Workshop participants were asked questions related to behaviors and attitudes (see Tables 6 and 7). Behavioral 


\begin{tabular}{|c|c|c|c|c|}
\hline \multirow[b]{2}{*}{ Location of activity } & \multicolumn{2}{|c|}{ Pretest } & \multicolumn{2}{|c|}{ Posttest } \\
\hline & Average & SD & Average & SD \\
\hline Ethiopia & $55.37 \mathrm{~B}^{a}$ & 14.06 & $63.52 \mathrm{~A}$ & 9.67 \\
\hline Uganda & 44.33 в & 9.03 & $63.94 \mathrm{~A}$ & 6.47 \\
\hline Mozambique & 57.22 в & 9.19 & $73.33 \mathrm{~A}$ & 15.13 \\
\hline
\end{tabular}

${ }^{a}$ Different letters (A and B) within a row shows statistically significant data $(P \leq 0.05)$.

questions (Table 6) were evaluated by using a 5-point Likert scale, with the opportunity to answer, "I do not know." More than half of the participants (70\% in Uganda, $80 \%$ in Mozambique, and 58\% in Ethiopia) strongly agreed that GLP affect the quality of the tests they conduct in the facilities; by the end of the training, most participants strongly agreed with this statement (100\% in Uganda, $82 \%$ in Mozambique, and $72 \%$ in Ethiopia). For questions, such as the effect of protective coverings (e.g., lab coats, shoe coverings, and gloves) on the impact of quality in laboratory testing, participant responses were different for each country. After the program, participants from Mozambique "strongly" believe ( $85 \%$ ) that protective coverings have some impact; however, the responses from the Ugandan (55\%) and Ethiopian (41\%) participants were less encouraging when compared with Mozambican participants. As a result of the workshop, participants also strongly agreed with the importance of "quality management systems" (e.g., ISO/IEC 17025 ), with 80,70 , and $53 \%$ in agreement before in Uganda, Mozambique, and Ethiopia and 100, 91, and 67\% afterwards, respectively. Similar responses were observed for equipment calibration: participants from Uganda and Mozambique agreed or strongly agreed (100\%) to the process, except for the participants from Ethiopia (89\%). Likewise, participants clearly understand the importance of training ( $70 \%$ before); however, interest grew because of the workshop (90\%), with many wishing to participate in similar types of training in the future. Similarly, participants strongly agreed on the value of lab work and its economic impact for their country, the region, and the world.

The attitude of participants before and after the program is reported in Table 7. Similar to behavioral questions, attitudinal questions were asked on a 5-point Likert scale, including "I do not know." Questions asked were related to general food safety practices, implementation, policies, inspection, and training. Before the program, $69 \%$ of the participants in Ethiopia, $80 \%$ in Uganda, and $100 \%$ in Mozambique agreed or strongly agreed on the effect of knowledge on SOP and the impact on the quality of the tests being conducted. After the program, agreed and strongly agreed responses increased to $100 \%$ in Uganda. Ethiopian participants also increased agreement to $95 \%$ after the program. The Mozambique participant responses remained the same throughout the workshop (100\%). Likewise, participant responses on training-related statements were evaluated. When asked if "this food testing laboratory has a responsibility to train individuals working in this lab on standard operating procedures," participant agreements increased from 90 to $100 \%$ in Uganda and 56 to $80 \%$ in Mozambique, while the Ethiopians responses remained the same (79\%) before and after the training. There were participants who did not provide an opinion related to "written SOP, good manufacturing practices (GMP) are equally important for the best results" in Uganda (10\%) and Ethiopia (5\%). After the delivery of the program, the strongly agreed responses for this statement increased from 90 to $100 \%$ in Uganda and 79 to $89 \%$ in Ethiopia. In Mozambique, $100 \%$ of the participants strongly agreed or agreed with the statement before and after the program. Initially, Ethiopians did not agree with the importance of local, regional, state or governmental regulations to keep food safe (5\%), but after the training, $100 \%$ strongly agreed. Participants from other countries responded similarly after the program. Likewise, most participants' attitudes toward the role of different agencies on certification of testing methods increased after the program: 90 to 100\% in Uganda and from 84 to $90 \%$ in Ethiopia. However, Mozambicans agreed 100\% before and after the program.

Another training program conducted in Africa (13) also demonstrated the positive effects of a training program on participants' good hygiene practices. To observe constant improved behavior and attitudes, training programs should be conducted continuously and be incorporated with a competency-based training curriculum framework (10) for food and feed testing laboratory personnel. This type of framework can serve as professional development by encouraging laboratory personnel participation in trainings. Finally, establishing 


\section{TABLE 6. Behavior of participants before and after the delivery of the Food Safety}

Laboratory Workshopa

GLP

Uganda before (\%)

Uganda after (\%)

My level of knowledge on GLP affects the quality of the tests

I conduct.

My behavior about GLP affects the quality of the tests I conduct.

Frocks, lab coats, or other coverings designated for the testing area only prevent errors in laboratory testing.

Separate shoes or shoe coverings designated for the testing area only prevent errors in laboratory testing.

Use of gloves prevents errors in laboratory testing.

Handwashing prevents errors in laboratory testing.

It is important to sanitize my working area (e.g., benchtop)

before starting my laboratory activities.

\begin{tabular}{|c|c|c|c|c|c|c|c|c|c|c|c}
\hline \multicolumn{5}{|c|}{ Uganda before (\%) } & \multicolumn{6}{c}{ Uganda after (\%) } \\
\hline SD & D & N & A & SA & IDNK & SD & D & N & A & SA & IDNK \\
\hline 0 & 0 & 0 & 30 & 70 & 0 & 0 & 0 & 0 & 0 & 100 & 0 \\
\hline 0 & 0 & 0 & 50 & 50 & 0 & 0 & 0 & 0 & 0 & 100 & 0 \\
\hline 10 & 30 & 0 & 40 & 20 & 0 & 10 & 0 & 0 & 50 & 40 & 0 \\
\hline 10 & 30 & 0 & 40 & 20 & 0 & 10 & 0 & 0 & 20 & 70 & 0 \\
\hline 10 & 30 & 0 & 50 & 10 & 0 & 0 & 10 & 0 & 20 & 70 & 0 \\
\hline 0 & 10 & 10 & 50 & 20 & 10 & 0 & 10 & 0 & 0 & 90 & 0 \\
\hline 0 & 0 & 0 & 20 & 80 & 0 & 0 & 0 & 0 & 10 & 90 & 0 \\
\hline
\end{tabular}

Quality management systems

Quality management systems (e.g., ISO/IEC 17025) are cumbersome.

Quality management systems (e.g., ISO/IEC 17025)

are necessary.

Quality management systems (e.g., ISO/IEC 17025)

prevent testing errors.

Equipment calibration prevents testing errors.

I follow all instructions in the quality management system my laboratory has in place.

My manager makes the objectives of the quality management system clear to employees.

\section{Training}

\begin{tabular}{l|c|c|c|c|c|c|c|c|c|c|c|c|c|c|c|}
\hline $\begin{array}{l}\text { I received training on GLP before I started working in } \\
\text { this laboratory. }\end{array}$ & 0 & 10 & 0 & 60 & 30 & 0 & 0 & 10 & 0 & 10 & 80 & 0 \\
\hline I receive refresher training on GLP annually. & 0 & 50 & 20 & 30 & 0 & 0 & 20 & 20 & 20 & 20 & 20 & 0 \\
\hline $\begin{array}{l}\text { Refresher trainings on GLP are a waste of time for } \\
\text { experienced technicians. }\end{array}$ & 50 & 50 & 0 & 0 & 0 & 0 & 80 & 20 & 0 & 0 & 0 & 0 \\
\hline \begin{tabular}{l} 
I enjoy training new technicians. \\
\hline I am confident in my ability to generate reliable results.
\end{tabular} & 0 & 0 & 10 & 80 & 10 & 0 & 0 & 0 & 0 & 30 & 70 & 0 \\
\hline $\begin{array}{l}\text { I would like to receive more training than I do. } \\
\text { International }\end{array}$ & 0 & 0 & 0 & 40 & 60 & 0 & 0 & 0 & 0 & 10 & 90 & 0 \\
\hline $\begin{array}{l}\text { The work my laboratory conducts is important for the economic } \\
\text { success of my region and country. }\end{array}$ & 0 & 0 & 0 & 20 & 80 & 0 & 0 & 0 & 0 & 0 & 100 & 0 \\
\hline $\begin{array}{l}\text { The work my laboratory conducts is important for the economic } \\
\text { success of my country, especially in international and global terms. }\end{array}$ & 0 & 0 & 0 & 30 & 70 & 0 & 0 & 0 & 0 & 0 & 100 \\
\hline $\begin{array}{l}\text { Having reliable testing laboratories means that the food products } \\
\text { produced in the country and region are safe. }\end{array}$ & 0 & 10 & 0 & 20 & 70 & 0 & 0 & 0 & 0 & 30 & 70 & 0 \\
\hline $\begin{array}{l}\text { Cooperation among counties, especially testing laboratory } \\
\text { standards and techniques, increases food safety. }\end{array}$ & 0 & 0 & 0 & 40 & 60 & 0 & 0 & 0 & 0 & 10 & 90 & 0 \\
\hline $\begin{array}{l}\text { Reliable testing laboratories are important for imported and } \\
\text { exported food. }\end{array}$ & 0 & 0 & 0 & 0 & 100 & 0 & 0 & 0 & 0 & 0 & 100 \\
\hline
\end{tabular}




\section{TABLE 6. Behavior of participants before and after the delivery of the Food Safety Laboratory Workshopa (cont.]}

\begin{tabular}{|c|c|c|c|c|c|c|c|c|c|c|c|c|}
\hline \multirow[b]{2}{*}{ GLP } & \multicolumn{6}{|c|}{ Mozambique before (\%) } & \multicolumn{6}{|c|}{ Mozambique after (\%) } \\
\hline & SD & $\mathrm{D}$ & $\mathbf{N}$ & A & SA & IDNK & SD & $\mathrm{D}$ & $\mathbf{N}$ & A & SA & IDNK \\
\hline $\begin{array}{l}\text { My level of knowledge on GLP affects the quality of the tests } \\
\text { I conduct. }\end{array}$ & 0 & 0 & 0 & 10 & 80 & 10 & 0 & 0 & 0 & 18 & 82 & 0 \\
\hline My behavior about GLP affects the quality of the tests I conduct. & 0 & 0 & 0 & 10 & 80 & 10 & 0 & 0 & 0 & 9 & 91 & 0 \\
\hline $\begin{array}{l}\text { Frocks, lab coats, or other coverings designated for the testing area } \\
\text { only prevent errors in laboratory testing. }\end{array}$ & 0 & 0 & 0 & 20 & 50 & 30 & 0 & 0 & 0 & 18 & 82 & 0 \\
\hline $\begin{array}{l}\text { Separate shoes or shoe coverings designated for the testing area } \\
\text { only prevent errors in laboratory testing. }\end{array}$ & 0 & 0 & 0 & 30 & 60 & 10 & 0 & 0 & 0 & 9 & 91 & 0 \\
\hline Use of gloves prevents errors in laboratory testing. & 0 & 0 & 0 & 40 & 60 & 0 & 0 & 0 & 9 & 9 & 82 & 0 \\
\hline Handwashing prevents errors in laboratory testing. & 0 & 0 & 0 & 30 & 70 & 0 & 0 & 0 & 0 & 9 & 91 & 0 \\
\hline $\begin{array}{l}\text { It is important to sanitize my working area (e.g., benchtop) before } \\
\text { starting my laboratory activities. }\end{array}$ & 0 & 0 & 0 & 10 & 80 & 10 & 0 & 0 & 0 & 27 & 73 & 0 \\
\hline \multicolumn{13}{|l|}{ Quality management systems } \\
\hline $\begin{array}{l}\text { Quality management systems (e.g., ISO/IEC 17025) } \\
\text { are cumbersome. }\end{array}$ & 0 & 10 & 10 & 20 & 50 & 10 & 0 & 36 & 27 & 9 & 27 & 0 \\
\hline $\begin{array}{l}\text { Quality management systems (e.g., ISO/IEC 17025) } \\
\text { are necessary. }\end{array}$ & 0 & 0 & 0 & 20 & 70 & 10 & 0 & 0 & 0 & 9 & 91 & 0 \\
\hline $\begin{array}{l}\text { Quality management systems (e.g., ISO/IEC 17025) } \\
\text { prevent testing errors. }\end{array}$ & 0 & 0 & 0 & 10 & 80 & 10 & 0 & 0 & 0 & 9 & 91 & 0 \\
\hline Equipment calibration prevents testing errors. & 0 & 0 & 0 & 10 & 80 & 10 & 0 & 9 & 0 & 9 & 82 & 0 \\
\hline $\begin{array}{l}\text { I follow all instructions in the quality management system my } \\
\text { laboratory has in place. }\end{array}$ & 0 & 0 & 0 & 20 & 70 & 10 & 0 & 0 & 0 & 9 & 91 & 0 \\
\hline $\begin{array}{l}\text { My manager makes it clear to employees as to the objectives of } \\
\text { the quality management system. }\end{array}$ & 0 & 0 & 0 & 20 & 70 & 10 & 0 & 0 & 9 & 27 & 64 & 0 \\
\hline \multicolumn{13}{|l|}{ Training } \\
\hline $\begin{array}{l}\text { I received training on GLP before I started working in } \\
\text { this laboratory. }\end{array}$ & 0 & 0 & 30 & 20 & 30 & 20 & 0 & 0 & 18 & 27 & 55 & 0 \\
\hline I receive refresher training on GLP annually. & 0 & 0 & 40 & 20 & 20 & 20 & 0 & 27 & 18 & 45 & 9 & 0 \\
\hline $\begin{array}{l}\text { Refresher trainings on GLP are a waste of time for } \\
\text { experienced technicians. }\end{array}$ & 20 & 0 & 0 & 30 & 10 & 40 & 27 & 55 & 0 & 9 & 9 & 0 \\
\hline I enjoy training new technicians. & 0 & 0 & 0 & 50 & 50 & 0 & 0 & 0 & 9 & 36 & 55 & 0 \\
\hline I am confident in my ability to generate reliable results. & 0 & 0 & 10 & 0 & 70 & 20 & 0 & 0 & 0 & 0 & 91 & 9 \\
\hline I would like to receive more training than I do. & 0 & 0 & 0 & 10 & 80 & 10 & 0 & 0 & 0 & 0 & 100 & 0 \\
\hline \multicolumn{13}{|l|}{ International } \\
\hline $\begin{array}{l}\text { The work my laboratory conducts is important for the economic } \\
\text { success of my region and country. }\end{array}$ & 0 & 0 & 0 & 0 & 90 & 10 & 0 & 0 & 0 & 0 & 100 & 0 \\
\hline $\begin{array}{l}\text { The work my laboratory conducts is important for the economic } \\
\text { success of my country especially in international and global terms. }\end{array}$ & 0 & 0 & 0 & 20 & 70 & 10 & 0 & 0 & 0 & 18 & 82 & 0 \\
\hline $\begin{array}{l}\text { Having reliable testing laboratories means that the food products } \\
\text { produced in the country and region are safe. }\end{array}$ & 0 & 10 & 0 & 30 & 50 & 10 & 0 & 0 & 0 & 18 & 82 & 0 \\
\hline $\begin{array}{l}\text { Cooperation among counties, especially testing laboratory } \\
\text { standards and techniques, increases food safety. }\end{array}$ & 0 & 0 & 0 & 10 & 80 & 10 & 0 & 0 & 0 & 0 & 100 & 0 \\
\hline $\begin{array}{l}\text { Reliable testing laboratories are important for imported and } \\
\text { exported food. }\end{array}$ & 0 & 0 & 0 & 10 & 80 & 10 & 0 & 0 & 0 & 0 & 100 & 0 \\
\hline
\end{tabular}




\section{TABLE 6. Behavior of participants before and after the delivery of the Food Safety}

Laboratory Workshopa (cont.)

\begin{tabular}{|c|c|c|c|c|c|c|c|c|c|c|c|c|}
\hline \multirow[b]{2}{*}{ GLP } & \multicolumn{6}{|c|}{ Ethiopia before (\%) } & \multicolumn{6}{|c|}{ Ethiopia after (\%) } \\
\hline & SD & $\mathrm{D}$ & $\mathbf{N}$ & A & SA & IDNK & SD & $\mathrm{D}$ & $\mathbf{N}$ & A & SA & IDNK \\
\hline $\begin{array}{l}\text { My level of knowledge on GLP affects the quality of the tests } \\
\text { I conduct. }\end{array}$ & 0 & 11 & 11 & 16 & 58 & 5 & 0 & 0 & 0 & 28 & 72 & 0 \\
\hline My behavior about GLP affects the quality of the tests I conduct. & 5 & 11 & 5 & 16 & 53 & 11 & 6 & 0 & 0 & 28 & 67 & 0 \\
\hline $\begin{array}{l}\text { Frocks, lab coats, or other coverings designated for the testing area } \\
\text { only prevent errors in laboratory testing. }\end{array}$ & 11 & 16 & 5 & 32 & 26 & 11 & 17 & 22 & 0 & 17 & 39 & 0 \\
\hline $\begin{array}{l}\text { Separate shoes or shoe coverings designated for the testing area } \\
\text { only prevent errors in laboratory testing. }\end{array}$ & 11 & 21 & 21 & 11 & 37 & 5 & 22 & 17 & 6 & 11 & 44 & 0 \\
\hline Use of gloves prevents errors in laboratory testing. & 0 & 0 & 5 & 26 & 58 & 5 & 11 & 0 & 0 & 28 & 61 & 0 \\
\hline Handwashing prevents errors in laboratory testing. & 5 & 5 & 0 & 32 & 53 & 5 & 6 & 0 & 0 & 22 & 72 & 0 \\
\hline $\begin{array}{l}\text { It is important to sanitize my working area (e.g., benchtop) } \\
\text { before starting my laboratory activities. }\end{array}$ & 0 & 0 & 0 & 5 & 63 & 32 & 0 & 0 & 0 & 0 & 72 & 28 \\
\hline \multicolumn{13}{|l|}{ Quality management systems } \\
\hline $\begin{array}{l}\text { Quality management systems (e.g., ISO/IEC 17025) } \\
\text { are cumbersome. }\end{array}$ & 32 & 16 & 5 & 21 & 16 & 11 & 44 & 17 & 0 & 6 & 22 & 11 \\
\hline $\begin{array}{l}\text { Quality management systems (e.g., ISO/IEC 17025) } \\
\text { are necessary. }\end{array}$ & 0 & 0 & 0 & 26 & 68 & 5 & 0 & 0 & 0 & 0 & 100 & 0 \\
\hline $\begin{array}{l}\text { Quality management systems (e.g., ISO/IEC 17025) } \\
\text { prevent testing errors. }\end{array}$ & 0 & 0 & 0 & 21 & 63 & 16 & 6 & 0 & 0 & 17 & 67 & 11 \\
\hline Equipment calibration prevents testing errors. & 0 & 0 & 0 & 11 & 74 & 16 & 6 & 0 & 0 & 22 & 67 & 6 \\
\hline $\begin{array}{l}\text { I follow all instructions in the quality management system } \\
\text { my laboratory has in place. }\end{array}$ & 0 & 0 & 11 & 21 & 58 & 16 & 0 & 0 & 0 & 11 & 83 & 6 \\
\hline $\begin{array}{l}\text { My manager makes the objectives of the quality management } \\
\text { system clear to employees. }\end{array}$ & 5 & 0 & 11 & 26 & 37 & 16 & 0 & 6 & 6 & 17 & 67 & 6 \\
\hline \multicolumn{13}{|l|}{ Training } \\
\hline $\begin{array}{l}\text { I received training on GLP before I started working in } \\
\text { this laboratory. }\end{array}$ & 5 & 5 & 21 & 37 & 16 & 16 & 0 & 0 & 17 & 17 & 61 & 6 \\
\hline I receive refresher training on GLP annually. & 21 & 11 & 11 & 26 & 16 & 16 & 0 & 17 & 11 & 28 & 39 & 6 \\
\hline $\begin{array}{l}\text { Refresher trainings on GLP are a waste of time for experienced } \\
\text { technicians. }\end{array}$ & 58 & 16 & 11 & 5 & 0 & 5 & 50 & 17 & 0 & 6 & 22 & 6 \\
\hline I enjoy training new technicians. & 0 & 0 & 26 & 16 & 47 & 11 & 0 & 0 & 6 & 22 & 67 & 6 \\
\hline I am confident in my ability to generate reliable results. & 0 & 5 & 11 & 26 & 47 & 11 & 0 & 0 & 6 & 28 & 56 & 11 \\
\hline I would like to receive more training than I do. & 5 & 0 & 11 & 11 & 58 & 16 & 0 & 0 & 6 & 6 & 78 & 11 \\
\hline \multicolumn{13}{|l|}{ International } \\
\hline $\begin{array}{l}\text { The work my laboratory conducts is important for the economic } \\
\text { success of my region and country. }\end{array}$ & 0 & 5 & 5 & 16 & 63 & 11 & 0 & 0 & 0 & 17 & 72 & 11 \\
\hline $\begin{array}{l}\text { The work my laboratory conducts is important for the economic } \\
\text { success of my country, especially in international and global terms. }\end{array}$ & 0 & 5 & 0 & 16 & 63 & 16 & 0 & 0 & 0 & 22 & 67 & 11 \\
\hline $\begin{array}{l}\text { Having reliable testing laboratories means that the food products } \\
\text { produced in the country and region are safe. }\end{array}$ & 11 & 5 & 11 & 16 & 53 & 5 & 17 & 0 & 0 & 11 & 61 & 11 \\
\hline $\begin{array}{l}\text { Cooperation among counties, especially testing laboratory } \\
\text { standards and techniques, increases food safety. }\end{array}$ & 0 & 5 & 0 & 16 & 74 & 5 & 0 & 0 & 0 & 17 & 72 & 11 \\
\hline $\begin{array}{l}\text { Reliable testing laboratories are important for imported and } \\
\text { exported food. }\end{array}$ & 0 & 0 & 5 & 21 & 68 & 5 & 0 & 0 & 0 & 17 & 72 & 11 \\
\hline
\end{tabular}

${ }^{a}$ SD, strongly disagree; D, disagree; N, neutral; A, agree; SA, strongly agree; IDNK, I do not know. 


\section{TABLE 7. Attitude of participants before and after the delivery of the Food Safety Laboratory Workshopa}

\begin{tabular}{|c|c|c|c|c|c|c|c|c|c|c|c|c|}
\hline \multirow[b]{2}{*}{ General food safety practices } & \multicolumn{6}{|c|}{ Uganda before (\%) } & \multicolumn{6}{|c|}{ Uganda after (\%) } \\
\hline & SD & $\mathrm{D}$ & $\mathbf{N}$ & A & SA & IDNK & SD & $\mathrm{D}$ & $\mathbf{N}$ & A & SA & IDNK \\
\hline $\begin{array}{l}\text { 1. My level of knowledge on SOP affects the quality of tests } \\
\text { I conduct. }\end{array}$ & 0 & 10 & 10 & 20 & 60 & 0 & 0 & 0 & 0 & 0 & 100 & 0 \\
\hline 2. Good personal hygiene practice helps make food safe to eat. & 0 & 0 & 0 & 0 & 100 & 0 & 0 & 0 & 0 & 0 & 100 & 0 \\
\hline $\begin{array}{l}\text { 3. Good personal hygiene is always important to run safe tests in } \\
\text { the laboratory. }\end{array}$ & 0 & 0 & 0 & 10 & 90 & 0 & 0 & 0 & 0 & 13 & 88 & 0 \\
\hline $\begin{array}{l}\text { 4. I believe my decisions impact the test results that I conduct in } \\
\text { the laboratory. }\end{array}$ & 0 & 0 & 0 & 40 & 60 & 0 & 0 & 0 & 0 & 0 & 100 & 0 \\
\hline $\begin{array}{l}\text { 5. This food testing laboratory has a responsibility to train } \\
\text { individuals working in this lab on good personal hygiene. }\end{array}$ & 0 & 0 & 0 & 20 & 80 & 0 & 0 & 0 & 0 & 0 & 100 & 0 \\
\hline $\begin{array}{l}\text { 6. This food testing laboratory has a responsibility to train } \\
\text { individuals working in this lab on SOP. }\end{array}$ & 0 & 0 & 0 & 10 & 90 & 0 & 0 & 0 & 0 & 0 & 100 & 0 \\
\hline $\begin{array}{l}\text { 7. It is important to record which employees in the laboratory } \\
\text { handle food allergens. }\end{array}$ & 0 & 0 & 10 & 20 & 70 & 0 & 0 & 0 & 0 & 25 & 75 & 0 \\
\hline \multicolumn{13}{|l|}{ Implementation, policies, inspection, and training } \\
\hline $\begin{array}{l}\text { 8. Internal audits are necessary to observe the implementation of } \\
\text { general food safety practices. }\end{array}$ & 0 & 0 & 10 & 20 & 70 & 0 & 0 & 0 & 0 & 0 & 100 & 0 \\
\hline $\begin{array}{l}\text { 9. As a laboratory technician/manager, I am as equally responsible } \\
\text { as others to produce the best results. }\end{array}$ & 0 & 0 & 0 & 0 & 80 & 20 & 0 & 0 & 0 & 0 & 100 & 0 \\
\hline $\begin{array}{l}\text { 10. I am a certified technician/manager, so my food testing results } \\
\text { should be accurate. }\end{array}$ & 0 & 0 & 10 & 20 & 60 & 10 & 0 & 0 & 25 & 25 & 50 & 0 \\
\hline $\begin{array}{l}\text { 11. The more I use the instruments in the laboratory, the more I } \\
\text { increase my skills. }\end{array}$ & 0 & 0 & 10 & 20 & 70 & 0 & 0 & 0 & 0 & 13 & 88 & 0 \\
\hline $\begin{array}{l}\text { 12. Written SOPs and good manufacturing practices are equally } \\
\text { important for the best results. }\end{array}$ & 0 & 0 & 0 & 0 & 90 & 10 & 0 & 0 & 0 & 0 & 100 & 0 \\
\hline $\begin{array}{l}\text { 13. Every employee/staff member should be trained before } \\
\text { working in this laboratory. }\end{array}$ & 0 & 0 & 0 & 20 & 80 & 0 & 0 & 0 & 0 & 0 & 100 & 0 \\
\hline $\begin{array}{l}\text { 14. It is important to have local/regional/state/governmental } \\
\text { regulations to keep food safe. }\end{array}$ & 0 & 0 & 0 & 20 & 80 & 0 & 0 & 0 & 0 & 0 & 100 & 0 \\
\hline $\begin{array}{l}\text { 15. Local/regional/state/governmental regulatory authorities } \\
\text { should inspect this facility on a regular basis. }\end{array}$ & 0 & 0 & 0 & 20 & 80 & 0 & 0 & 0 & 0 & 13 & 88 & 0 \\
\hline $\begin{array}{l}\text { 16. The food testing laboratory has a responsibility to train } \\
\text { individual workers. }\end{array}$ & 0 & 0 & 0 & 10 & 90 & 0 & 0 & 0 & 0 & 0 & 100 & 0 \\
\hline $\begin{array}{l}\text { 17. I believe it is important to have regular training sessions } \\
\text { for employees. }\end{array}$ & 0 & 0 & 0 & 20 & 80 & 0 & 0 & 0 & 0 & 13 & 88 & 0 \\
\hline \multirow[t]{2}{*}{$\begin{array}{l}\text { 18. It is important to be certified by local/regional/ } \\
\text { governmental/international agencies on our testing methods. }\end{array}$} & 0 & 0 & 0 & 10 & 90 & 0 & 0 & 0 & 0 & 0 & 100 & 0 \\
\hline & \multicolumn{6}{|c|}{ Mozambique before (\%) } & \multicolumn{6}{|c|}{ Mozambique after (\%) } \\
\hline General food safety practices & SD & $\mathrm{D}$ & $\mathbf{N}$ & A & SA & IDNK & SD & $\mathrm{D}$ & $\mathbf{N}$ & A & SA & IDNK \\
\hline $\begin{array}{l}\text { 1. My level of knowledge on SOP affects the quality of tests } \\
\text { I conduct. }\end{array}$ & 0 & 0 & 0 & 22 & 78 & 0 & 0 & 0 & 0 & 30 & 70 & 0 \\
\hline 2. Good personal hygiene practice helps make food safe to eat. & 0 & 0 & 0 & 22 & 78 & 0 & 0 & 0 & 0 & 20 & 80 & 0 \\
\hline $\begin{array}{l}\text { 3. Good personal hygiene is always important to run safe tests in } \\
\text { the laboratory. }\end{array}$ & 0 & 0 & 0 & 22 & 78 & 0 & 0 & 0 & 0 & 0 & 100 & 0 \\
\hline $\begin{array}{l}\text { 4. I believe my decisions impact the test results that I conduct in } \\
\text { the laboratory. }\end{array}$ & 0 & 0 & 0 & 11 & 89 & 0 & 0 & 0 & 0 & 10 & 90 & 0 \\
\hline
\end{tabular}




\section{TABLE 7. Attitude of participants before and after the delivery of the Food Safety Laboratory Workshopa (cont.)}

\begin{tabular}{|c|c|c|c|c|c|c|c|c|c|c|c|c|}
\hline \multirow[b]{2}{*}{ General food safety practices } & \multicolumn{6}{|c|}{ Mozambique before (\%) } & \multicolumn{6}{|c|}{ Mozambique after (\%) } \\
\hline & SD & $\mathrm{D}$ & $\mathbf{N}$ & A & SA & IDNK & SD & $\mathrm{D}$ & $\mathbf{N}$ & A & SA & IDNK \\
\hline $\begin{array}{l}\text { 5. This food testing laboratory has a responsibility to train } \\
\text { individuals working in this lab on good personal hygiene. }\end{array}$ & 0 & 0 & 0 & 33 & 67 & 0 & 0 & 0 & 0 & 30 & 70 & 0 \\
\hline $\begin{array}{l}\text { 6. This food testing laboratory has a responsibility to train } \\
\text { individuals working in this lab on SOP. }\end{array}$ & 0 & 0 & 0 & 44 & 56 & 0 & 0 & 0 & 0 & 20 & 80 & 0 \\
\hline $\begin{array}{l}\text { 7. It is important to record which employees in the laboratory } \\
\text { handle food allergens. }\end{array}$ & 0 & 0 & 0 & 56 & 44 & 0 & 0 & 0 & 0 & 20 & 80 & 0 \\
\hline \multicolumn{13}{|l|}{ Implementation, policies, inspection, and training } \\
\hline $\begin{array}{l}\text { 8. Internal audits are necessary to observe the implementation of } \\
\text { general food safety practices. }\end{array}$ & 0 & 0 & 0 & 11 & 89 & 0 & 0 & 0 & 0 & 20 & 80 & 0 \\
\hline $\begin{array}{l}\text { 9. As a laboratory technician/manager, I am as equally responsible } \\
\text { as others to produce the best results. }\end{array}$ & 0 & 0 & 0 & 11 & 89 & 0 & 0 & 0 & 0 & 20 & 80 & 0 \\
\hline $\begin{array}{l}\text { 10. I am a certified technician/manager, so my food testing results } \\
\text { should be accurate. }\end{array}$ & 0 & 0 & 0 & 22 & 78 & 0 & 0 & 0 & 0 & 20 & 80 & 0 \\
\hline $\begin{array}{l}\text { 11. The more I use the instruments in the laboratory, the more I } \\
\text { increase my skills. }\end{array}$ & 0 & 0 & 0 & 22 & 78 & 0 & 0 & 0 & 0 & 10 & 90 & 0 \\
\hline $\begin{array}{l}\text { 12. Written SOPs and good manufacturing practice are equally } \\
\text { important for the best results. }\end{array}$ & 0 & 0 & 0 & 0 & 100 & 0 & 0 & 0 & 0 & 20 & 80 & 0 \\
\hline $\begin{array}{l}\text { 13. Every employee/staff member should be trained before } \\
\text { working in this laboratory. }\end{array}$ & 0 & 0 & 0 & 0 & 100 & 0 & 0 & 0 & 0 & 30 & 70 & 0 \\
\hline $\begin{array}{l}\text { 14. It is important to have local/regional/state/governmental } \\
\text { regulations to keep food safe. }\end{array}$ & 0 & 0 & 0 & 22 & 78 & 0 & 0 & 0 & 0 & 40 & 60 & 0 \\
\hline $\begin{array}{l}\text { 15. Local/regional/state/governmental regulatory authorities } \\
\text { should inspect this facility on a regular basis. }\end{array}$ & 0 & 0 & 0 & 33 & 67 & 0 & 0 & 0 & 0 & 30 & 70 & 0 \\
\hline $\begin{array}{l}\text { 16. The food testing laboratory has a responsibility to train } \\
\text { individual workers. }\end{array}$ & 0 & 0 & 0 & 22 & 78 & 0 & 0 & 0 & 0 & 40 & 60 & 0 \\
\hline $\begin{array}{l}\text { 17. I believe it is important to have a regular training sessions } \\
\text { for employees. }\end{array}$ & 0 & 0 & 0 & 11 & 89 & 0 & 0 & 0 & 0 & 40 & 60 & 0 \\
\hline \multirow[t]{2}{*}{$\begin{array}{l}\text { 18. It is important to be certified by local/regional/ } \\
\text { governmental/international agencies on our testing methods. }\end{array}$} & 0 & 0 & 0 & 22 & 78 & 0 & 0 & 0 & 0 & 30 & 70 & 0 \\
\hline & \multicolumn{6}{|c|}{ Ethiopia before (\%) } & \multicolumn{6}{|c|}{ Ethiopia after (\%) } \\
\hline General food safety practices & SD & $\mathrm{D}$ & $\mathbf{N}$ & A & SA & IDNK & SD & $\mathrm{D}$ & $\mathbf{N}$ & A & SA & IDNK \\
\hline $\begin{array}{l}\text { 1. My level of knowledge on SOP affects the quality of tests } \\
\text { I conduct. }\end{array}$ & 0 & 11 & 16 & 11 & 58 & 5 & 0 & 5 & 0 & 32 & 63 & 0 \\
\hline 2. Good personal hygiene practice helps make food safe to eat. & 0 & 0 & 0 & 26 & 74 & 0 & 0 & 0 & 0 & 11 & 95 & 0 \\
\hline $\begin{array}{l}\text { 3. Good personal hygiene is always important to run safe tests in } \\
\text { the laboratory. }\end{array}$ & 0 & 0 & 0 & 21 & 79 & 0 & 0 & 0 & 0 & 5 & 95 & 0 \\
\hline $\begin{array}{l}\text { 4. I believe my decisions impact the test results that I conduct in } \\
\text { the laboratory. }\end{array}$ & 0 & 5 & 5 & 26 & 47 & 16 & 5 & 5 & 5 & 21 & 63 & 0 \\
\hline $\begin{array}{l}\text { 5. This food testing laboratory has a responsibility to train } \\
\text { individuals working in this lab on good personal hygiene. }\end{array}$ & 0 & 0 & 0 & 11 & 89 & 0 & 0 & 0 & 0 & 11 & 89 & 0 \\
\hline $\begin{array}{l}\text { 6. This food testing laboratory has a responsibility to train } \\
\text { individuals working in this lab on SOP. }\end{array}$ & 0 & 0 & 5 & 16 & 79 & 0 & 0 & 0 & 0 & 21 & 79 & 0 \\
\hline $\begin{array}{l}\text { 7. It is important to record which employees in the laboratory } \\
\text { handle food allergens. }\end{array}$ & 0 & 0 & 11 & 11 & 79 & 0 & 11 & 0 & 0 & 21 & 68 & 0 \\
\hline
\end{tabular}




\section{TABLE 7. Attitude of participants before and after the delivery of the Food Safety Laboratory Workshopa (cont.)}

\begin{tabular}{|c|c|c|c|c|c|c|c|c|c|c|c|c|}
\hline \multirow[b]{2}{*}{ General food safety practices } & \multicolumn{6}{|c|}{ Ethiopia before (\%) } & \multicolumn{6}{|c|}{ Ethiopia after (\%) } \\
\hline & SD & $\mathrm{D}$ & $\mathbf{N}$ & A & SA & IDNK & SD & $\mathrm{D}$ & $\mathbf{N}$ & A & SA & IDNK \\
\hline \multicolumn{13}{|l|}{ Implementation, policies, inspection, and training } \\
\hline $\begin{array}{l}\text { 8. Internal audits are necessary to observe the implementation of } \\
\text { general food safety practices. }\end{array}$ & 0 & 5 & 0 & 16 & 79 & 0 & 0 & 0 & 0 & 32 & 63 & 5 \\
\hline $\begin{array}{l}\text { 9. As a laboratory technician/manager, I am as equally responsible } \\
\text { as others to produce the best results. }\end{array}$ & 5 & 0 & 0 & 21 & 74 & 0 & 0 & 0 & 0 & 5 & 89 & 5 \\
\hline $\begin{array}{l}\text { 10. I am a certified technician/manager, so my food testing results } \\
\text { should be accurate. }\end{array}$ & 0 & 5 & 11 & 37 & 42 & 5 & 0 & 5 & 11 & 11 & 68 & 5 \\
\hline $\begin{array}{l}\text { 11. The more I use the instruments in the laboratory, the more I } \\
\text { increase my skills. }\end{array}$ & 0 & 0 & 0 & 26 & 68 & 5 & 0 & 0 & 0 & 5 & 89 & 5 \\
\hline $\begin{array}{l}\text { 12. Written SOPs and good manufacturing practices are equally } \\
\text { important for the best results. }\end{array}$ & 0 & 0 & 0 & 16 & 79 & 5 & 0 & 0 & 0 & 11 & 89 & 0 \\
\hline $\begin{array}{l}\text { 13. Every employee/staff member should be trained before } \\
\text { working in this laboratory. }\end{array}$ & 0 & 0 & 5 & 16 & 79 & 0 & 0 & 0 & 0 & 11 & 89 & 0 \\
\hline $\begin{array}{l}\text { 14. It is important to have local/regional/state/governmental } \\
\text { regulations to keep food safe. }\end{array}$ & 5 & 0 & 0 & 5 & 89 & 0 & 0 & 0 & 0 & 11 & 89 & 0 \\
\hline $\begin{array}{l}\text { 15. Local/regional/state/governmental regulatory authorities } \\
\text { should inspect this facility on a regular basis. }\end{array}$ & 0 & 0 & 11 & 16 & 74 & 0 & 0 & 0 & 0 & 5 & 95 & 0 \\
\hline $\begin{array}{l}\text { 16. The food testing laboratory has a responsibility to train } \\
\text { individual workers. }\end{array}$ & 5 & 0 & 5 & 11 & 79 & 0 & 0 & 0 & 0 & 5 & 95 & 0 \\
\hline $\begin{array}{l}\text { 17. I believe it is important to have regular training sessions } \\
\text { for employees. }\end{array}$ & 0 & 0 & 0 & 21 & 79 & 0 & 0 & 0 & 0 & 11 & 89 & 0 \\
\hline $\begin{array}{l}\text { 18. It is important to be certified by a local/regional/ } \\
\text { governmental/international agencies on our testing methods. }\end{array}$ & 0 & 0 & 0 & 16 & 84 & 0 & 0 & 0 & 5 & 5 & 90 & 0 \\
\hline
\end{tabular}

${ }^{a} \mathrm{SD}$, strongly disagree; D, disagree; N, neutral; A, agree; SA, strongly agree; IDNK, I do not know.

equivalency of competencies among laboratories in the world has the potential to provide consistent, accurate, and reliable test results.

\section{CONCLUSIONS}

In this study, a curriculum was developed and disseminated to laboratory personnel of food safety laboratories on the basis of an earlier needs assessment (14). The curriculum included topics, such as lab safety, quality assurance, validation of test methods and equipment, sampling protocols, accreditation, data analysis, statistical process control, troubleshooting, record keeping, and training. The workshop was delivered to $\sim 45$ participants from food safety testing laboratories in Uganda, Mozambique, and Ethiopia.
As a result of the workshop, the knowledge, hand-washing skills, behaviors, and attitudes of laboratory personnel were significantly improved. These types of training and improvements may provide increased confidence in personnel to obtain accurate and reliable test results, which may also have the potential to produce a safer food supply.

\section{ACKNOWLEDGMENTS}

This research was funded by the U.S. Department of Agriculture Foreign Agriculture Service through an agreement with the U.S. Agency for International Development. The authors thank the participants of the program for contributions to the development, delivery, and results of this research study.

\section{REFERENCES}

1. African Agricultural Trade Status Report. 2017. Executive summary. Available at: http://agri.ckcest.cn/ass/NK00820170817011.pdf. Accessed 10 March 2021.
2. Benton, T. n.d. Food security, trade and its impacts. Available at: https://resourcetrade. earth/ stories/food-security-trade-and-itsimpacts\#top. Accessed 17 August 2020.
3. da Cunha, D. T., M. A. T. Cipullo, E. Stedefeldt, and V. V. de Rosso. 2015. Food safety knowledge and training participation are associated with lower stress and anxiety levels of Brazilian food handlers. Food Control 50:684-689. 
4. European Accreditation. 2002. Accreditation in microbiological laboratories. EA 4/10. Available at: http://www.europeanaccreditation.org/publications. Accessed 19 August 2020.

5. Food and Agriculture Organization of the United Nations. 2005. Annex 9. Available at: http://www.fao.org/3/a0215e/A0215E25. htm. Accessed 10 March 2021.

6. Food and Agriculture Organization of the United Nations. 2020. The state of food security and nutrition in the world. Available at: http://www.fao.org/publications/sofi/ en/. Accessed 10 March 2021.

7. Global Food Safety Partnership. n.d. Food safety in Africa. Past endeavors and future directions. Available at: https://www.gfsp. org/sites/gfsp/files/public/GFSP\%20 Report_Food\%20Safety\%20in\%20Africaweb.pdf. Accessed 18 August 2020.

8. Huu Vo, T., N. H. Le, A. T. N. Le, N. N. T. Minh, and J. P. Nuorti. 2015. Knowledge, attitudes, practices and training needs of food-handlers in large canteens in Southern Vietnam. Food Control 57:190-194.

9. Johnston, J. D., S. M. Thygerson, M. J. Johnson, and J. C. Reading. 2013. Hand washing quality among biosafety level 2 research laboratory workers. Appl. Biosaf. 18:116-121.
10. Kaml, C., C. C. Weiss, P. Dezendorf, M. Ishida, D. H. Rice, R. Klein, and Y. Salfinger. 2014. Developing a competency framework for U.S. state food and feed testing laboratory personnel. J. AOAC Int. 97:768-772.

11. Leavengood, S., and J. E. Reeb. 1999. Performance excellence in the wood products industry. Oregon State University Extension Service. Available at: https://ir.library. oregonstate. edu/downloads/vx021f499. Accessed 18 August 2020.

12. Machado, R. A. M., R. Radhakrishna, and C. N. Cutter. 2017. Food safety of farmstead cheese processors in Pennsylvania: an initial needs assessment. Food Prot. Trends 37:88-98.

13. Malavi, D. N., G. O. Abong, and T. Muzhingi. 2021. Effect of food safety training on behavior change of food handlers: a case of orange-fleshed sweet potato purée processing in Kenya. Food Control 119:107500.

14. Pokharel, S., R. A. M. Machado, and C. N. Cutter. 2018. A needs assessment of practices and procedures in African food safety testing laboratories. Food Prot. Trends 38:363-381.

15. Stevenson, R. L. 2012. Food safety practices: interview with international food safety training laboratory manager Janie Dubois. Available at: https://www. americanlaboratory.com/913-TechnicalArticles/118174-Food-Safety-PracticesInterview-With-International-Food-SafetyTraining-Laboratory-Manager-Janie-Dubois/. Accessed 3 September 2020.
16. The Joint Commission. 2009. Measuring hand hygiene adherence: overcoming the challenges. Available at: http://www. jointcommission.org/assets/1/18/hh monograph.pdf. Accessed 1 March $20 \overline{17}$.

17. U.S. Food and Drug Administration. 2013. Food/feed testing laboratories best practices manual. Available at: https://www.fda.gov/ media/87427/download. Accessed 9 March 2021 .

18. U.S. Food and Drug Administration, Office of Foods and Veterinary Medicine. 2015. Guidelines for the validation of analytical methods for the detection of microbial pathogens in foods and feeds. Available at: https://www.fda.gov/ downloads/ScienceResearch/FieldScience/ UCM298730.pdf. Accessed 5 September 2020.

19. World Health Organization. 2015. Food safety. Available at: https://www.afro.who. int/ health-topics/food-safety. Accessed 18 August 2020.

20. World Health Organization. 2015. WHO estimates of the global burden of foodborne diseases: foodborne disease burden epidemiology reference group 2007-2015. World Health Organization, Geneva. 